International Journal of Instruction e-ISSN: 1308-1470 • www.e-iji.net

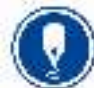

July $2021 \bullet$ Vol.14, No.3

p-ISSN: 1694-609X

pp. $847-860$

Article submission code: 20200507165146

Received: 07/05/2020

Revision: 27/01/2021
OnlineFirst: 19/06/2021
Accepted: 19/02/2021

\title{
Scientific Literacy Skills of Students: Problem of Biology Teaching in Junior High School in South Sulawesi, Indonesia
}

\author{
Adnan \\ Dr., Drs., M.S. Universitas Negeri Makassar, Indonesia, adnan@ unm.ac.id \\ Usman Mulbar \\ Prof., Dr., M.Pd., Universitas Negeri Makassar, Indonesia, umulbar@unm.ac.id \\ Sugiarti \\ Dr., Dra., M.Si. Universitas Negeri Makassar, Indonesia, atisugiarti34@yahoo.co.id
}

\section{Arsad Bahri}

Dr., S.Pd, M.Pd, Universitas Negeri Makassar, Indonesia, arsad.bahri@unm.ac.id

|

The aim of this study was to determine the scientific literacy skills of students at junior high school (JHS) in biology teaching in South Sulawesi, Indonesia. This research was a survey research. Sampling was selected through a progressive random sampling technique with stratification. The research samples were four junior high schools, they are: JHS 4 Makassar, JHS 26 Makassar, JHS 2 Maros, and JHS 4 Sinjai with the total samples were 235 students. Each school was represented by 2 classes. The results of research showed that the students of junior high school who were able to understand the inquiry method that leads to scientific knowledge as much as $17.02 \%$, and ability to organize, analyse, and interpret the quantitative data and scientific information as much as $36.23 \%$. Overall, the conclusion of this study was the scientific literacy of junior high school students in biology teaching was still low. The constructivist learning method should be used by the teacher, such us using inquiry method and completed by an innovative media and learning resources to enhance students' scientific literacy.

Keywords: scientific literacy, science learning, constructivist paradigm, inquiry learning, $21^{\text {th }}$ century skills

\section{INTRODUCTION}

Basically, every human being has a great curiosity about science, but it must be recognized that not all are able to understand science easily. Especially in learning in the schools it takes a long process to shape the quality of personal learners in science. The development of the 21st century provided various demands for each individual to be able to follow developments in the fields of science and technology (Ozdem, et al.,

Citation: Adnan., Mulbar, U., Sugiarti., \& Bahri, A. (2021). Scientific literacy skills of students: problem of biology teaching in junior high school in south Sulawesi, Indonesia. International Journal of Instruction, 14(3), 847-860. https://doi.org/10.29333/iji.2021.14349a 
2010). Trilling and Fadel (2009) and Bahri, et al. (2019) stated that the students have to master various skills that relevant to the five pillars of education in 21st century (learning to believe in God, to know, to do, to be, and to live together). Rahayu (2017) stated that the skills grouped as $21^{\text {th }}$ century skills into four major groups, namely: digital-age literacy, life skills, effective communication, and high productivity.

Science has a great influence on people's private lives and the global economy. Science was very important to develop the quality of human resources (Bahri, et al. (2021). To be successful in this century, students must have good scientific literacy skills and principles for life-long learning (Solmaz, 2017; Novaristiana, et. al., 2019; Hernawati, et. al., 2019), and thinking skills (Bahri, et al., 2021). Kuhlthau (2010) explained that good reading skills will accustom students read to learn and have the ability to understand the material. Scientific literacy is important for everyone to have a greater chance to adapt in life, especially in terms of mastering the ability to read in order to enhance the development of a the country.

Scientific literacy skills made students could distinguish several scientific facts from a lot of information, recognize and analyse the use of scientific inquiry methods as well as the ability to analyse, organize, interpret quantitative data and scientific information (Gormally, et. al., 2012). Suwono et al., (2019) stated that science literacy was the scientifically thinking ability, and critically, and to use scientific knowledge to develop decision-making skills.

Science education is now a form of reformation or change to the previous education system in the context of the availability of scientific literacy. According to Holbrook and Rannikmae (2009), learning scientific literacy is learning that leads to selfdevelopment in honing abilities and creativity based on the scientific knowledge that is relevant to daily life and Fakhriyah et al. (2017) stated that scientific literacy skills play a role in supporting students in making decisions to solve problems. Furthermore, Lederman et al. (2013) explained that scientific literacy could be promoted by the skill of problem solving in personal and social life.

When related to the meaning of scientific literacy, it can be seen from two groups, namely the science literacy group and the scientific literacy group. The science literacy group explained that the main aspect of scientific literacy is the understanding of science content (the science basic concepts) (Holbrook \& Raniikmae, 2009). The scientific literacy group explained that scientific literacy is associated with the development of life skills which means that it was needed for reasoning skills in a social context and emphasizes that scientific literacy is intended for everyone. According to Dani (2009), a framework for scientific literacy consisted of four aspects: knowledge of science, science as a way of thinking, investigation of the science nature, and interaction between science, technology, and society.

Related to the scientific literacy capabilities, Indonesia took part in international assessments namely TIMSS (Trends International Mathematics and Science Study) and 
PISA (Program for International Student Assessment). TIMSS 2015 result showed Indonesia ranked 44 out of 49 countries with an average rating of 397. TIMSS assessment information shows that students' scientific skills at TIMSS are still below the international average of 500 and generally at the lowest level (Low International Benchmark). The analysis of the PISA 2018 result shows that the quality of Indonesia's education is ranked 72 out of 78 countries in mathematics, ranked 70 out of 78 countries in science, and ranked 72 out of 77 countries in reading (OECD, 2019). This illustrated the ability of scientific literacy of students in Indonesia, which was still low. Therefore, the problems that occur must be immediately sought a solution to suppress the emergence of a problem or a greater challenge and overcome the problems that are happening. In this case, it is important to enhance the students' scientific literacy skills, which certainly requires a large role from educators to build these skills.

The low of scientific literacy skills of Indonesian students as one of skills required in $21^{\text {st }}$ century including in biology classroom need to be a concern nowadays. Mukti, et al. (2019) said that the students should master these skills, so they could be able to apply scientific knowledge to solve science problems. Choi, et. al. (2011) explained that students could solve their problems in everyday life trough scientific literacy skills. The results of research conducted by Sulistiawati (2015), Suwono, et al. (2019), Hernawati, et al. (2019), and Novaristiana, et al. (2019) showed the low of scientific literacy skills biology students. The research finding of Suwono, et al. (2019) was also guaranteed by scientific literacy tests, which come from Test of Scientific Literacy Skill (TOSLS). The results showed that the low scientific literacy of students indicates that it is necessary to increase students' scientific literacy. The low scientific literacy ability of these students certainly has links that are interrelated with science learning at the level of education below, especially at the secondary education level like junior high school (JHS). Dewi, et al. (2017) found that the science literacy skills of JHS students still very low before giving a treatment with the discovery learning.

Biology learning seeks the formation of students as human beings who have the capital of scientific literacy that is human who open up their self-sensitivity, examine, filter, apply, and contribute to develop science and technology to improve the welfare and benefit of society. Toharudin et al., (2011) stated that scientific literacy consisted of the ability to identify questions and draw a conclusion based on facts to understand the nature, to make a decision from changes occurred due to human activities thus having attitude and high sensitivity, and to communicate in writing or orally. So that scientific literacy is seen as multidimensional which is not only an understanding of scientific knowledge, but can enhance the ability to think and associate the understanding of knowledge gained with daily life and understand the relationship of science with other disciplines (Suwono, et al., 2009).

Several studies have been conducted by the researchers to develop variety instruments to assess aspects of individual scientific literacy skills, but there is no single instrument that can be used to measure all skills. Rusilowati, et al. (2016) used four scientific literacy categories as an instrument of scientific literacy assessment as follow: science 
as a body of knowledge (category A), science as a way of investigating (category B), science as a way of thinking (category $\mathrm{C}$ ), and the interaction between science, technology, and society (category D). Two surveys often used for international comparisons of scientific literacy include questions about non-laboratory science process skills, such as to define science, and items that measure vocabulary and basis content knowledge (basic content knowledge). Specifically scientific reasoning instruments were developed to assess critical thinking and reasoning of students (Gormally, et al., 2012). Arend (2009) stated that critical thinking is seen as an indispensable life skill. The process of improving thinking basically creates habits of reflection and questions every aspect of life. The high order thinking skills such as critical thinking must be trained to the students, but tend to practice focus on students' memorization efforts or assignments given at a lower cognitive level.

So far, previous studies were not provided the comprehensive data about the profile of the JHS students' scientific literacy in biology teaching in South Sulawesi, Indonesia. Based on this fact, it is important to conduct the research regarding to the profile of the JHS students' scientific literacy in biology teaching in South Sulawesi, which will be useful to provide information for teachers, so they can improve the teaching quality that can enhance students' scientific literacy in biology. The objectives of this study was to get an overview of the scientific literacy profile of JHS students in South Sulawesi based on the type of school. This research focussed to answer the question about the ability of students to understand the inquiry method that leads to scientific knowledge and ability to analyse, organize, and interpret scientific information and quantitative data.

\section{METHOD}

\section{Research Design}

This study was collecting quantitative data as the survey research. The researchers analyzing the data to describe trends about the answers of research questions from the results of scientific literacy-based test instruments. The next stage also interprets the meaning of the data obtained.

\section{Participants and Sampling Technique}

The sample of this study was choosed by progressive random sampling with stratification. The research was located in Makassar City, Sinjai regency, and Maros regency. The selected location represented big city, middle city, and small city. For schools in Makassar City, conducted in 2 schools, namely JHS 6 Makassar as much 63 students and JHS 26 Makassar as much as 53 students, in Maros Regency JHS 2 Maros as much as 60 students, and in Sinjai Regency, JHS 4 Sinjai as much as 59 students were selected with the total participants as much as 235 students of $8^{\text {th }}$ grade. Each school represented the upper type (high grade/favorite), medium type, and lower type schools in South Sulawesi. 


\section{Instruments}

The Test of Scientific Literacy Skill (TOSLS) consisting of 13 numbers that have been instrument used in this study. The instrument has been validated by two experts by referring to the scientific literacy indicators. The result of expert validation showed that the validation category was strongly valid (average from two experts was 3.6). For empirical validation by using Microsoft Excel, the result of analysis showed that the instruments were valid (0.385-0.701) and reliable (0.978). In this study an assessment and analysis of junior high school students' scientific literacy skills was carried out based on indicators of scientific literacy in terms of two aspects (Gormally, et al., 2012), namely: 1) understanding the inquiry method that leads to scientific knowledge, consisting of (a) identifying the valid scientific arguments, (b) conducting effective literature search (c) evaluating the use and misuse of scientific information, (d) understanding elements of research design, 2) organizing, analysing, and interpreting quantitative data and scientific information, consisting of (a) making graphs appropriately from data, (b) reading and interpreting graphs correctly from data, (c) solving problems using quantitative skills, including basic statistics, (d) understanding and interpreting basic statistics and (e) performing inferences, predictions, and drawing conclusions based on quantitative data.

\section{Procedure of the Implementation}

This research procedure began by giving the students with tests based on scientific literacy skills indicators at the end of course at the odd semester. The double choice problem developed covers all biological concepts at JHS grade $7^{\text {th }}$ and $8^{\text {th }}$. Each biological concept represented by one number of test. The instrument used in this study, namely Test of Scientific Literacy Skill (TOSLS) consisting of 13 numbers by referring to scientific literacy indicators. The time of the test is 45 minutes. The research instrument used was a scientific literacy test in the form of multiple-choice with four choices. The result of expert validation showed that the test instruments were valid by referring to scientific literacy indicators. The percentage of student's answers based on existing indicators was grouped to determine the level of scientific literacy.

\section{Data Analysis}

Data of the scientific literacy skill in biology science were analyzed descriptively based on the formula (1) by Arikunto (2005):

Scientific Literacy Skills $=\frac{\text { number of correct gcores } x}{\text { number of maximum gcores }} \times 100 \%$

Scientific literacy skills of biological science scores were further grouped into several categories by modified from Purwanto (2009), namely very good (grades 86-100), good (grades 76-85), quite good (grades 60-75), low (grades 55-59) and very low (grades less than 54). While the percentage of students who were able to answer the scientific 
literacy test correctly were grouped into: very high (>80\%), high (70\%-79.99\%), moderate (60\%-69.99\%), low (50\%-59.99\%) and very low $(<50 \%)$.

\section{FINDINGS}

The information about the scientific literacy skills of junior high school students in biology teaching in South Sulawesi was obtained based on the results of data analysis. The average score of scientific literacy skills of biology science of students at four junior high schools in South Sulawesi as presented in Table 1.

Table 1

Profile of scientific literacy at four junior high schools in south Sulawesi

\begin{tabular}{lll}
\hline Name of School & Average Score & Category \\
\hline JHS 6 Makassar & 37.48 & Very low \\
\hline JHS 26 Makassar & 27.58 & Very low \\
\hline JHS 2 Maros & 28.08 & Very low \\
\hline JHS 4 Sinjai & 32.20 & Very low \\
\hline \multicolumn{1}{c}{ Average } & 31.34 & Very low
\end{tabular}

The average literacy ability of biology science in junior high school students in South Sulawesi was 31.34 (very low) from a range of 0 to 100 (Table 1). This study also found that the percentage of students' ability to answer biology scientific literacy questions based on TOSLS indicator understanding the inquiry method that leads to scientific knowledge are presented at Table 2.

Table 2

Percentage of biology scientific literacy skills of students in indicator understanding the inquiry method that leads to scientific knowledge

\begin{tabular}{llllll}
\hline Science Literacy Skills Indicator & $\begin{array}{l}\mathrm{A} \\
(\%)\end{array}$ & $\begin{array}{l}\mathrm{B} \\
(\%)\end{array}$ & $\begin{array}{l}\mathrm{C} \\
(\%)\end{array}$ & $\begin{array}{l}\mathrm{D} \\
(\%)\end{array}$ & $\begin{array}{l}\text { Total } \\
(\%)\end{array}$ \\
\hline identifying the valid scientific arguments & 13.21 & 0 & 6.67 & 6.78 & 6.38 \\
\hline conducting an effective literature search & 30.19 & 7.94 & 11.67 & 10.17 & 14.47 \\
\hline $\begin{array}{l}\text { evaluating the use and misuse of scientific } \\
\text { information }\end{array}$ & 49.06 & 11.11 & 16.67 & 25.42 & 24.68 \\
\hline understanding the elements of research design & 12.26 & 36.51 & 15.83 & 23.73 & 22.55 \\
\hline \multicolumn{1}{c}{ Average } & $\begin{array}{l}26.18 \\
\text { (very } \\
\text { low) }\end{array}$ & $\begin{array}{l}13.89 \\
\text { (very } \\
\text { low) }\end{array}$ & $\begin{array}{l}12.71 \\
\text { (very } \\
\text { low) }\end{array}$ & $\begin{array}{l}16.53 \\
\text { (very } \\
\text { low) }\end{array}$ & $\begin{array}{l}17.02 \\
\text { (very } \\
\text { low) }\end{array}$ \\
\hline Note: A J JSS 26
\end{tabular}

Note: A= JHS 26 Makassar, $\mathrm{B}=$ JHS 6 Makassar, $\mathrm{C}=$ JHS 2 Maros, \& $\mathrm{D}=\mathrm{JHS} 4$ Sinjai

The ability of students in identifying the valid scientific arguments, conducting an effective literature search, evaluating the use and misuse of scientific information, and understanding the elements of research design were in the very low category (Table 2). Overall, the percentage of students who were able to answer science literacy questions on biology that emphasize the ability of students to conduct inquiry was below the $50 \%$ rate for all categories, both viewed by students at each school, or combined for all students at all schools. 
The result of research about the students' scientific literacy in biology science in indicators organizing, analysing, and interpreting quantitative data and scientific information are presented at Table 3.

Table 3

Percentage of biology science literacy skills of students in junior high school in indicator organizing, analysing, and interpreting quantitative data and scientific information

\begin{tabular}{|c|c|c|c|c|c|}
\hline Science Literacy Skills Indicator & $\begin{array}{l}\mathrm{A} \\
(\%)\end{array}$ & $\begin{array}{l}\mathrm{B} \\
(\%)\end{array}$ & $\begin{array}{l}\mathrm{C} \\
(\%)\end{array}$ & $\begin{array}{l}\mathrm{D} \\
(\%)\end{array}$ & $\begin{array}{l}\text { Total } \\
(\%)\end{array}$ \\
\hline making the graphs appropriately from data & 47.17 & 47.70 & 38.33 & 45.76 & 44.70 \\
\hline $\begin{array}{l}\text { reading and interpreting the graphs correctly } \\
\text { from data }\end{array}$ & 9.43 & 85.71 & 31.67 & 28.81 & 40.43 \\
\hline $\begin{array}{l}\text { solving the problems using quantitative skills, } \\
\text { including basic statistics }\end{array}$ & 37.74 & 50.79 & 35.00 & 54.24 & 44.68 \\
\hline $\begin{array}{l}\text { understanding and interpreting the basic } \\
\text { statistics }\end{array}$ & 7.55 & 3.17 & 5.00 & 6.78 & 5.53 \\
\hline $\begin{array}{l}\text { performing the inferences, predictions, and } \\
\text { drawing conclusions based on quantitative data }\end{array}$ & 28.92 & 52.90 & 50.00 & 49.15 & 45.81 \\
\hline Average & $\begin{array}{l}48.05 \\
\text { (very } \\
\text { low) }\end{array}$ & $\begin{array}{l}26.16 \\
\text { (very } \\
\text { low) }\end{array}$ & $\begin{array}{l}32.00 \\
\text { (very } \\
\text { low) }\end{array}$ & $\begin{array}{l}36.95 \\
\text { (very } \\
\text { low) }\end{array}$ & $\begin{array}{l}36.23 \\
\text { (very } \\
\text { low) }\end{array}$ \\
\hline
\end{tabular}

Note: A= JHS 26 Makassar, B= JHS 6 Makassar, C= JHS 2 Maros, \& D= JHS 4 Sinjai

In general the scientific literacy skills of students in junior high school students on biology teaching in indicator making the graph appropriately from the data, reading and interpreting the graphs correctly from the data, solving the problems using quantitative skills, including basic statistics, understanding and interpreting the basic statistics, and performing the inferences, predictions, and drawing conclusions based on quantitative data were still failed. Overall the percentage of students who were able to answer questions that emphasize the ability to organize, analyze, and interpret quantitative data and scientific information was still below $50 \%$. The ability to understand and interpret basic statistics need to get more attention, because out of 235 students, only $5.53 \%$ students were able to answer questions correctly. However, when viewed based on students in each school unit, it is seen that the percentage of students who are able to read and interpret graphics in JHS Negeri 6 Makassar reaches $85.71 \%$ with a very good category (Table 3).

\section{DISCUSSION}

The scientific literacy ability of junior high school students in biological science literacy in South Sulawesi, Indonesia was still low. The previous study from Adnan, et. al. (2021) and Sugiarti, et. al. (2021) also showed the same results. The average score of scientific literacy of biology science in junior high school students in South Sulawesi was 31.34 from a range of 0 to 100 . The questions given refer to the TOSLS by Gormally, et al., (2012) with an emphasis on students' abilities in identifying scientific opinions, effective literature search, evaluating the use and misuse of information and 
understanding elements of research design, making graphs, interpreting graphs, solving problems, understanding and interpreting basic statistics, and carrying out information, predictions and drawing conclusions. If the various categories are examined well, it is very clearly unraveled that to improve the biology literacy ability of junior high school students, the learning paradigm used should lead to a constructivist paradigm.

Constructivist paradigm is based on the statement that students learn by actively organizing and making meaning of information in their own way. Constructivist paradigm believes that the students do not learn by directly memorizing information from the outside world or by transferring knowledge from teachers to students. In this way, students build their own knowledge or meaningful ideas by connecting newly received information to their knowledge and experience. This also implied that students learn in their own way and their learning approaches were student-centered and cognitive learning (Haruthaithanasan, 2010).

The percentage of students who understand the inquiry method that leads to scientific knowledge as well as the ability to organize, analyze, and interpret quantitative data and scientific information was still relatively. Beside that, the low percentage of students who were able to reason in the context of the inquiry as the basis of biological science literacy skills. The low literacy ability of biological science is inseparable from the role of the teacher as implementing learning in the classroom. This show inconsistent variations in the percentage of students who are able to answer scientific literacy questions (Table 1 and 2). It can be assumed from this fact that the students' ability to solve scientific questions is largely determined by the ability of teachers to facilitate learning in the classroom. Scientists studied natural sciences (including biology) through certain scientific processes and attitudes. For example, the process is through experiments, while scientific attitudes are objective and honest when collecting and analyzing data. By using scientific processes and attitudes, scientists obtain discoveries that can be in the form of facts or theories and the findings are called natural products. Thus in broad outline the components of the Natural Sciences consist scientific attitudes, scientific processes, and scientific products.

The findings of research indicated that biology teaching in junior high school was not associated with real life contexts, learning rarely starts from actual problems, science learning in schools tends to depart from subject matter not from the main objectives of science learning and the needs of the students. This is in line with Yuliati (2017) research found that learning science tends to only anticipate examinations, caused the low of students' understanding of the inquiry method and are unable to organize, analyze, and interpret quantitative data and scientific information.

To improve students' abilities in aspects of science literacy and scientific literacy, the principles of constructivist learning must be applied in the classes. Haruthaithanasan (2010) stated that the characteristics of constructivist learning were needed teacher scaffolding, including the guidance from teachers to achieve assignments, difficult challenging tasks, and learning and motivation encouragement. Collaborative learning 
could become one characteristic of constructivist learning, including learning communities, group assignments, share knowledge, learning together and helping each other. Holbrook and Raniikmae (2009) suggested that scientific literacy could impact students to know about why it is necessary to learn science. It will build the students' perceptions and attitudes about the needs, importance, usefulness, and meaningfulness of learning science. It will also build the students' participation and motivation in learning science, so they want to act and learn. Finally, it is important to create science learning situation referring to the ideas of scientific literacy comprehensively.

In constructivist learning, through the conditioning students can be trained to (a) Identify scientific arguments appropriately, (b) Carry out effective literature searches (c) Evaluate the use and misuse of scientific information, (d) Understand the elements in research design. In this way, students build their own knowledge by linking newly received information to their previous knowledge and experience. Haruthaithanasan (2010) supported that it could implied that students learn in their own way and their learning approaches are centered on students and cognitive learning.

Therefore teachers should act as guides and facilitator in class so that students can concept and initiative. The teacher must be a designer of the learning environment, study space, and academic consultants for students. Jia (2010) stated that teachers should apply the principles of constructivist learning and view students as the center with the teacher guidance. The teacher facilitates, organizes and guides the overall learning process.

The empowerment of the skills mentioned above was considered essential as students are trained to indetify the best arguments. This is in line with Ramdiah, et al. (2019) stated that from this training could produced insights into certain meanings and interpretations as the product of logical reasoning patterns. Shukla and Dungsungnoen (2016) suggested that this skills enable students to see concepts holistically and reflect an effective, sceptical, curious, able to revise beliefs, flexible thinker attitude, be analytical, sensitive to the context of current issues, and persistent by thinking deeply.

Other principles of constructivist learning were believed to enhance the students' scientific literacy ability through reflective thinking. Reflective thinking refers to including stimulating thinking skills, instruction in the form of teacher questions, and evaluating critical knowledge. Knowledge cannot be transferred from teacher to students. The essence of constructivism is that students actively build knowledge. Students are expected to construct their own knowledge by searching, making decisions, using higher-level thinking skills and their own creativity, and collaborative learning. Bas (2012) explained that constructivist learning paradigm was based on the students' participation actively in problem solving, creative and critical thinking. Haruthaithanasan (2010) and Listiana and Bahri (2019) found that the learning process with problem-solving and investigation, stimulating skills and the process of inquiry in solving problems and conducting research, as well as learning discovery. These learning activities were relevance to daily-life, including learning in daily life (in authentic situations) and at work and relevant to student experiences. 
Learning according to the view of constructivism is more a process of self-regulation in resolving cognitive conflicts that often arise through concrete experiences, collaborative discourse, and interpretation. However, cognitive conflict needs to be considered in deeply in various situations. Schunk (2012) found that through cognitive conflict, students can be directed to organize, analyze, and interpret quantitative data and scientific information, such as (a) Make graphs correctly from data, (b) Read and interpret graphs appropriately from data, (c) Solve problems using quantitative skills, including basic statistics, (d) Understand and interpret basic statistics and (e) Perform inferences, predictions, and draw conclusions based on quantitative data. Thus the teacher should build the situations that can make students be actively involved in learning process. One way was involved with the subject matter through the processing of materials and social interactions.

To train the students with scientific literacy skills, science teachers play an important role in facilitating students to develop scientific literacy skills. The teachers are required to provide effective learning situation for students, so they can develop the knowledge and nature of science investigations. Students also can understand and communicate science with oral and written vocabulary and they can make the relationship between science, technology, and society. Ergul, et al., (2011) suggested that teachers need to understand comprehensively about the nature of science and be able to effectively communicate this understanding to students. Mukti, et al. (2019) suggested that an innovative learning to empower students' scientific literacy skills needs to be introduced to biology learning. This is in line with Rahayu (2017) suggested that the teachers could enhance scientific literacy of students by facilitated the students to have appropriate experience in science activities, investigation and/or experimentation. Everything can be enhance through innovative learning strategy or model that is built by incorporating the elements needed for scientific literacy skills. Then, it will develop collaboration \& communication skills, and curiosity of students.

\section{CONCLUSION}

The scientific literacy ability of students in junior high school in biology teaching in South Sulawesi was still low. The results of research showed that percentage of junior high school students who are able in understanding the inquiry method that leads to scientific knowledge as much as $17.02 \%$, and ability to organize, analyze, and interpret quantitative data and scientific information as much as $36.23 \%$.

The implication of this research is to demand improvement in the study of biological science in South Sulawesi. The teacher in fact applies the constructivist learning principles as required in the school curriculum to realize more effective learning at the junior high school level. Through the constructivist learning application, it is expected that the learning process emphasizes more on the achievement of products, processes, and scientific attitudes. In addition, it is necessary to monitor and evaluate how the school implement the curriculum in the classroom. 


\section{ACKNOWLEDGEMENT}

This project was supported and funded by Research and Community Service Institute, Universitas Negeri Makassar. We would like to thank to Husain Syam as who has contributed in the completion of this paper.

\section{REFERENCES}

Adnan, Mulbar, U., Sugiarti, \& Bahri, A. (2021). Biology Science Literacy of Junior High School Students in South Sulawesi, Indonesia. Journal of Physics: Conference Series, 1752 (2021) 012084, 1- 9. doi:10.1088/1742-6596/1752/1/012084

Arend, B. (2009). Encouraging Critical Thinking in Online Threaded Discussions. The Journal of Educators Online, 6(1), 1-23.

Arikunto, S. (2005). Dasar-dasar Evaluasi Pendidikan. (Fundamental of Educational Evaluation). Jakarta: PT. Bumi Aksara. (in Indonesian).

Bahri, A., Idris, I.S., Nurman, R., \& Ristiana, E. (2019). PBLRQA Strategy Potential in Enhancing Metacognitive Skills of Students with Different Academic Achievement. Journal of Physics: Conf. Series, 1317, (012199), 1-9. doi:10.1088/17426596/1317/1/012199.

Bahri, A., Idris, I. S., Muis, H., Arifuddin, M., \& Fikri, M., J., N. (2021). Blended Learning Integrated with Innovative Learning Strategy to Improve Self-Regulated Learning. International Journal of Instruction, 14(1), 779-794. https://doi.org/10.29333/iji.2021.14147a.

Bahri, A., Jamaluddin, A. B., Muharni, A., Fikri, M. J. N., \& Arifuddin, M. (2021). The Need of Science Learning to Empower High Order Thinking Skills in 21st Century. Journal of Physics: Conference Series, 1899 (2021) 012144, 1-8. doi: 10.1088/17426596/1899/1/012144.

Bas, G. (2012). Investigating The Correlation Between Students' Perceptions on The Constructivist Learning Environment and Their Academic Success in Science Course with Path Analysis. Journal of Baltic Science Education, 11(4), 367-379.

Choi, K., Lee, H., Shin, N., Kim, S., \& Krajcik, J. (2011). Re-conceptualization of Scientific Literacy in South Korea for The 21st century. Journal of Research in Teaching, 48(6), 670-697. doi: https://doi.org/ 10.1002/tea.20424.

Dani, D. (2009). Scientific Literacy and Purposes for Teaching Science: A Case Study of Lebanese Private School Teachers. International Journal of Environmental \& Science Education, 4(3), 289-299.

Dewi, S.R., Nurmilawati, M., \& Budiretnani, D.A. (2017). Improving of Scientific Literacy Ability using Discovery Learning Model at The Seventh Grade Students of State JHS 3 Ngronggot, Nganjuk-Indonesia. Jurnal Pendidikan Biologi Indonesia, 3(3), 266-271. https://doi.org/10.22219/jpbi.v3i3.4540

Eggen, P. \& Kauchak, D. (2012). Strategi dan Model Pembelajaran Mengajarkan 
Konten dan Keterampilan Berpikir, Edisi Keenam (Learning Strategies and Models for Teaching Content and Thinking Skills, Sixth Edition). Jakarta: Indeks. (in Indonesian).

Ergül, R., Simsekli, Y., Çaliù, S., Özdolekùirin, Z., Göçmençelebo, S., \& Sanli. M. (2011). The Effects of Inquiry-Basedscience Teaching on Elementary school Students' Science Processskills and Science Attitudes. Bulgarian Journal of Science and Education Policy, 5(1), 48-68.

Fakhriyah, F., Masfuah, S., Roysa, M., \& Rahayu, S. (2017). Student's Science Literacy in The Aspect of Content Science? Jurnal Pendidikan IPA Indonesia, 6(1), 81-87.

Gormally, C, Peggy B., \& Mary L. (2012). Developing A Test of Scientific Literacy Skill (TOSLS): Measuring Undergraduates Evaluation of Scientific Information and Argument. Journal CBE-Life Science, 11(12), 364-377.

Haruthaihanasan, T. (2010). The Effects of Experiences with Constructivist Instruction on Attitude toward Democracy among Thai College Students. Desertation, the Faculty of the Graduate School at the University of Missouri.

Hernawati, D., Amin, M., Muhdhar, M.H.I.A., \& Indriwati, S. E. (2019). Science Literacy Skills through The Experience of Project Activities with Assisted Local Potential Based Learning Materials. Jurnal Pendidikan Biologi Indonesia, 5(1), 159168.

Holbrook, J., \& Rannikmae, M. (2009). The Meaning of Scientific Literacy. International Journal of Environmental \& Science Education, 4(3), 144-150.

Jia, Q. (2010). A Brief Study on the Implication of Constructivism Teaching Theory on Classroom Teaching Reform in Basic Education. International Education Studies, 3(2), 197-199.

Kuhlthau, C. C. (2010). Guided Inquiry: School Libraries in the $21^{\text {st }}$ Century. School Libraries Worldwide, 16(1), 17-28.

Lederman, N. G., Lederman, J. S., \& Antink, A. (2013). Nature of Science and Scientific Inquiry as Contexts for The Learning of Science and Achievement of Scientific Literacy. International Journal of Education in Mathematics, Science and Technology, 1(3), 138-147.

Listiana, L., \& Bahri, A. (2019). Empowering Student's Creative Thinking Skill in Biology Classroom: Potential of Group Investigation Combined with Think Talk Write (GITTW) Strategy. Humanities \& Social Sciences Reviews, 7(3), 477-483. https://doi.org/10.18510/hssr.2019.7370.

Mukti, W.R., Yuliskurniawati, I.D., Noviyanti, N.I., Mahanal, S., \& Zubaidah, S. (2019). A Survey of High School Students's Scientific Literacy Skills in Different Gender. Journal of Physics: Conf. Series, 1241 (012043), 1-8. 
Novaristiana, R, Rinanto, Y., \& Ramli, M. (2019). Scientific Literacy Profile in Biological Science of High School Students. Jurnal Pendidikan Biologi Indonesia, 5(1), 9-16.

Özdem, Y., Çavaş, P., Çavaş, B., Cakıroğlu, J., Ertepınar, H. (2010). An Investigation of Elementary Students' Scientific Literacy Levels. Journal of Baltic Science Education, 9(1), 6-19.

OECD. (2016). PISA 2015 Result Excellence and Equity in Education. Volume I. Paris: OECD Publishing.

Purwanto, P. (2009). Evaluasi hasil belajar. (Evaluation of Learning Outcome). Bandung: PT. Remaja Rosdikarya. (in Indonesian).

Rahayu, S. (2017). Promoting the $21^{\text {st }}$ Century Scientific Literacy Skills through Innovative Chemistry Instruction. AIP Conference Proceedings, 1911(020025), 1-8.

Ramdiah, S., Abidinsyah, Royani, M., \& Husamah. (2019). Understanding, Planning, and Implementation of HOTS by Senior High School Biology Teachers in BanjarmasinIndonesia. International Journal of Instruction, 12(1), 425-440.

Rusilowati, A., Kurniawati, L., Nugroho, S.E., \& Widiyatmoko, A. (2016). Developing an Instrument of Scientific Literacy Assessment on the Cycle Theme, International Journal of Environmental and Science Education, 11(12), 5718-5727.

Schunk. D.H., (2012). Learning Theories an Education Perspective (Translated by Hamdiah Eva, Rahmat Fajar). Yogyakarta: Pustaka Pelajar.

Solmaz, D.Y. (2017). Relationship between Lifelong Learning Levels and Information Literacy Skills in Teacher Candidates. Universal Journal of Educational Research, 5(6): 939-946, DOI: 10.13189/ujer.2017.050605.

Suwono, H., \& Mulyaningsih, E. (2009). Model Trend Prestasi Siswa Berdasarkan Data PISA tahun 2000, 2003, dan 2006 (Trend Model of Students' Achievement Based on PISA 2000, 2003, and 2006 Data). Research Report. Jakarta: Pusat Pendidikan Badan Penelitian dan Pengembangan Departemen Pendidikan Nasional Publishing. (in Indonesian).

Suwono, H., Saefi, M., \& Susilo, H. (2019). Challenge-Based Learning to Improve Scientific Literacy of Undergraduate Biology Students. AIP Conference Proceedings, 2081, 030020. doi: 10.1063/1.5094018.

Sugiarti, Mulbar, U., Adnan, \& Bahri, A. (2021). Correlation between Teacher Guidance and Parent with Chemical Literation Ability of Junior High School Student. Journal of Physics: Conference Series, 1752 (2021) 012083, 1-10. doi:10.1088/1742$6596 / 1752 / 1 / 012083$

Sulistiawati. (2015). Analisa Pemahaman Literasi Sains Mahasiswa yang Mengambil Mata Kuliah IPA Terpadu Menggunakan Contoh Soal PISA 2009 (Analysis of 
Understanding of Science Literacy of Students Taking Integrated Science Courses Using The Example of PISA 2009 Questions), Sainteks, 12(1), 21-40. (in Indonesian).

Shukla, D., \& Dungsungnoen, A. P. (2016). Student's Perceived Level and Teachers' Teaching Strategies of Higher Order Thinking Skills; A study on Higher Educational Institutions in Thailand. Journal of Education and Practice, 7(12), 211-219.

Toharudin, U., Hendrawati, S,. \& Rustaman, A. 2011. Membangun Literasi Sains Peserta Didik. (Building The Student's Saintific Literacy). Bandung: Humaniora. (in Indonesian).

Trilling, B., \& Fadel, C. (2009). $21^{\text {th }}$ Century Skills. Learning for Life in Our Times. San Francisco: Wiley.

Yuliati, Y. (2017). Literasi Sains dalam Pembelajaran IPA (Saintific Literacy in Science Learning). Jurnal Cakrawala Pendas, 3(2), 21-28. (in Indonesian). 